\title{
The role of plant phenology in the host specificity of Gephyraulus raphanistri (Diptera: Cecidomyiidae) associated with Raphanus spp. (Brassicaceae)
}

\author{
Janine VITOU ${ }^{1}$, Marcela SKUHRAVÁ ${ }^{2}$, Václav SKUHRAVÝ ${ }^{2}$, John K. SCOTT ${ }^{3}$ and ANDy W. SHEPPARD \\ ${ }^{1}$ CSIRO European Laboratory, Campus International de Baillarguet, Montferrier-sur-Lez, France; \\ e-mail: janine.vitou@csiro-europe.org \\ ${ }^{2}$ Czech Zoological Society, Viničná 7, CZ-128 44 Praha 2, Czech Republic \\ ${ }^{3} \mathrm{CRC}$ for Australian Weed Management and CSIRO Entomology, Private Bag 5, PO Wembley, W.A. 6913, Australia
}

\begin{abstract}
Key words. Cecidomyiidae, Gephyraulus raphanistri, Brassicaceae, Raphanus raphanistrum, host-plant specificity, biological control, host-plant phenology
\end{abstract}

\begin{abstract}
Recent host records for Gephyraulus raphanistri (Kieffer), a flower-gall midge, show restriction to Raphanus raphanistrum throughout Europe. Gephyraulus raphanistri has never been reported infesting commercially grown Brassica crops. Historical records showing a broad host range appear to have resulted from confusion with new or as yet undescribed Gephyraulus spp. and Contarinia nasturtii (Kieffer), a known gall-former of Brassica and other related genera. This study tested host specificity of G. raphanistri in the field in Europe by manipulating host plant phenology of actual and potential hosts in the genera Raphanus and Brassica as part of a risk assessment of the insect as a potential biological control agent of $R$. raphanistrum, one of the most important weeds of crops in Australia. Raphanus raphanistrum raphanistrum (wild radish), $R$. raphanistrum landra (coastal wild radish), Raphanus sativus (radish) and Brassica napus (oilseed rape cultivar) were phenologically synchronised for initial flowering and planted out in a flowering time and species block design near a natural population of $R$. $r$. landra hosting a natural population of $G$. raphanistri. Three generation peaks in gall formation were observed in the experiment, with galls developing on all test plants with an apparent preference for $R$. r. landra. The high field specificity of this gall midge is driven by the synchrony of oviposition and flower availability, not host physiological incompatibility or behavioural unacceptability. Commercially grown Brassica spp. are not suitable hosts for G. raphanistri because in the field they differ in flowering phenology from Raphanus raphanistrum. The overlap in the flowering phenology of the crop and weed in Australia makes this insect unsuitable as a biological control agent.
\end{abstract}

\section{INTRODUCTION}

Of the 2200 gall midges species (Diptera: Cecidomyiidae) occurring in the Palaearctic Region, 76\% are phytophagous, $16 \%$ are mycophagous and $8 \%$ are zoophagous (Skuhravá et al., 1984; Skuhravá, 1986). Phytophagous gall midges, given the intimate relationship with their host plants, are generally highly host specific and sensitive to small differences in host-plant physiology, chemistry, development and phenology (Barnes, 1946; Skuhravá, 1986; Shorthouse \& Rohfritsch, 1992; Abrahamson et al., 1998). These characteristics added to their short lifecycle and multivoltinism even in cold temperate climates make these midges both formidable crop-specific pests (Barnes, 1946) and useful biological control agents of weeds (Harris \& Shorthouse, 1996). About 60 gall midges are pests of agriculture and forestry (Darvas et al., 2000; Skuhravá \& Roques, 2000; Harris, 2002).

The high degree of specificity of gall formers appears to result from the phytophagous insect having a high degree of specialization combined with the host plant's specific growth response following the unique feeding site activity of the gall former (Shorthouse \& Rohfritsch, 1992). This intimate co-evolutionary relationship between gall-formers and their hosts results in near monophagy in most gall formers. The fundamental host range (van Klinken \& Edwards, 2002; the insect's host range, based on physical, metabolic, sensory and behavioural optimal conditions) and the field host specificity (the realized host range observed in nature) are, therefore, largely the same (Peschken, 1982; Moore, 1991; Hinz, 1998; Sobhian et al., 2000). However, the relative importance of physiological suitability and behavioural acceptability versus phenological compatibility between the gall former and its host in defining field host specificity remains unstudied. Knowing what determines insect host specificity is of vital importance for understanding the evolution of insect plant relationships and risk assessment of biological control agents. Seven species of gall midge have been used for the biological control of weeds.

Three midge species are associated with cruciferous crops (cabbages, turnip, swede, rape, radish, etc.) in Europe. Larvae of Contarinia nasturtii (Kieffer) attack basal parts of stems, heart leaves and flower buds, larvae of Dasineura brassicae (Winnertz) attack siliquae preventing normal seed development and larvae of Gephyraulus raphanistri (Kieffer) live gregariously in swollen flower buds. The host plant range is, however, unclear (Barnes, 1946). G. raphanistri and C. nasturtii occur sometimes together in flower buds and it is unknown which species is the gall causer and which the inquiline. $G$. raphanistri and $C$. nasturtii galls are frequently mentioned in the cecidological literature, but $G$. raphanistri is seldom mentioned in the economic literature, suggesting 
it may have been overlooked or confused with $C$. nasturtii.

Raphanus contains two species, Raphanus sativus L. (edible radish) and $R$. raphanistrum L. with three subspecies; $R$. r. raphanistrum, $R$. r. landra (Moretti ex DC) Bonnier \& Layens, and R. r. rostratus (DC) Thell. Phylogenetic evidence points to a common ancestry for Raphanus spp. and Brassica napus L. (canola) (Gómez-Campo \& Prakash, 1999). This provides the context and focus for analyzing the detailed host specificity of $G$. raphanistri.

The historical literature suggests Gephyraulus raphanistri galls have been recorded from Raphanus raphanistrum (Kieffer, 1886) and up to 26 species of eight genera of the family Brassicaceae (Houard, 1908-1909; Buhr, 1939; Stelter, 1954). However many of these records appear to have been based on gall symptoms rather than clear taxonomic determination. More recent work has revealed previously undescribed Gephyraulus galling these hosts. For example, G. diplotaxis galls flowers of Diplotaxis muralis (Brassicaceae) (Solinas, 1982) and Fedotova (1992) described six new Gephyraulus species, each associated with a different host genus in the family Brassicaceae. Two independent surveys by the following authors (Scott et al., 2002, for Mediterranean France, Portugal and Tunisia; Skuhravá and colleagues for Europe: Austria (Skuhravá \& Franz, 1989), Bulgaria (Skuhravá et al., 1991, 1992), Czech Republic (Skuhravá, 1994a, b), Denmark (Skuhravá et al., 2006), France (Skuhravá et al., 2005), Italy (Skuhravá \& Skuhravý, 2005), Poland (Skuhravá \& Skrzypczynska, 1983), Portugal (Skuhravá et al., 1996), Slovakia (Skuhravá, 1991), Spain (Skuhravá et al., 1996) and Switzerland (Skuhravá \& Skuhravý, 1997), which included all available wild and crop species of Brassicaceae between 1956 and 2005 at 1770 localities throughout Europe and Tunisia only record G. raphanistri from $R$. raphanistrum. All recent evidence, therefore, indicates this gall midge is specific in the field to this host.

Raphanus raphanistrum raphanistrum (wild radish) in southern Australia is one of the most important weeds of annual crops. The development of widespread herbicide resistance in this weed has lead to the investigation of alternative means of control (Scott et al., 2002). The aim of this study was to understand the role of host plant phenology in the field in the host specificity of the gallforming cecidomyiid, G. raphanistri, a potential classical biological control agent of wild radish.

\section{MATERIAL AND METHODS}

\section{Field experiment}

The host use of $G$. raphanistri was tested in the field at Palavas les Flots, France from late April until $1^{\text {st }}$ July 2002. Three $2 \times 1 \mathrm{~m}$ blocks were set up; each containing 24 randomly arranged potted experimental plants; 6 of $R$. r. raphanistrum, 6 of R. r. landra, 6 of $R$. sativus and 6 of Brassica napus (Canola). Block 1 was set up on the 26 April, block 2 on the 30 April and block 3 on the 6 May 2002. These different dates were used to try and obtain a sequence of flowering phenology in the experimental plants across the blocks. Blocks 1, 2 and 3 were also 2 $\mathrm{m}, 6 \mathrm{~m}$ and $16 \mathrm{~m}$, respectively from a natural G. raphanistri population on naturally occurring $R$. r. landra.

Experimental plants used in the blocks were all sown in early January to minimize size differences and grown in a glasshouse within which the temperature was manipulated to ensure all the test plants flowered while there were naturally ovipositing $G$. raphanistri. Plants were transferred to their respective blocks at Palavas when the first flower buds were observed, so plants that flowered earliest, based on natural flowering phenology variation, were placed in block 1 and plants that flowered last were placed in block 3 .

On 6 May and then twice weekly until 1 July 2002, the experimental plants were watered and the numbers of flowers, galled and not galled were counted. Sampling covered the full flowering period of each plant and occurred over the three natural generations of $G$. raphanistri. On each visit a sample of about 10 galled flowers was collected from each of the four potted plant species and from the spontaneous $R$. r. landra plants. Each gall was placed in a separate Eppendorf tube and returned to the laboratory so that the 3 different larval stages, nymphs and adults, necessary for the identification, could be reared.

\section{Analysis}

To normalize the numerical data were log transformed prior to analysis. Comparisons of the number of flowers and galls per species were each analysed using one-way ANOVA in STATISTIX 8, 1985-2003 Analytical Software, Tallahassee, Florida.

The effect of flower number per plant (covariate), plant species and block on the number of galls per plant across the whole experimental period was analyzed using ANCOVA in GLIM 3.77, 1985 Royal Statistical Society, London.

Some of the test plants produced flower buds when the gall midge was not ovipositing, and therefore not available for oviposition. The effect of this was tested by comparing the within generation gall number. The number of flowers available and galls produced were collated for each plant species per block in each of the G. raphanistri generations; 6.v.-27.v., 27.v.-14.vi. and 14.vi.-1.vii., based on field data (Fig. 1). The effect of flower number per generation per block (covariate), plant species and generation number on the number of galls produced per generation per block was then also analysed using ANCOVA in GLIM.

\section{RESULTS}

Adult cecidomyiids were reared from larvae obtained from all four test plant species and the spontaneous $R$. $r$. landra plants. Gephyraulus raphanistri was the only gall midge species identified (by M. Skuhravá) from the galls during this experiment (the sample included 20 males and 4 females from $B$. napus; 11 males and 7 females from $R$. $r$. landra; 6 males and 5 females from $R$. r. raphanistrum and 12 males and 7 females from $R$. sativus).

All the 18 plants per species flowered. The average flowering period of individual experimental plants varied with plant $\left(\mathrm{F}_{3,71}=46.8, P<0.0001\right.$; Fig. 1$)$, with $B$. napus, $R$. sativus, $R$. r. raphanistrum and $R$. r. landra flowering for 15, 24, 31 and 39 days respectively. However, given the experimental design flowering phenology did vary between blocks, at least for B. napus, where the three blocks flowered asynchronously (Fig. 1).

Eighteen plants of $R$. r. landra, 17 of $R$. sativus, 15 of $R$. r. raphanistrum and 13 of $B$. napus had galled flowers. 

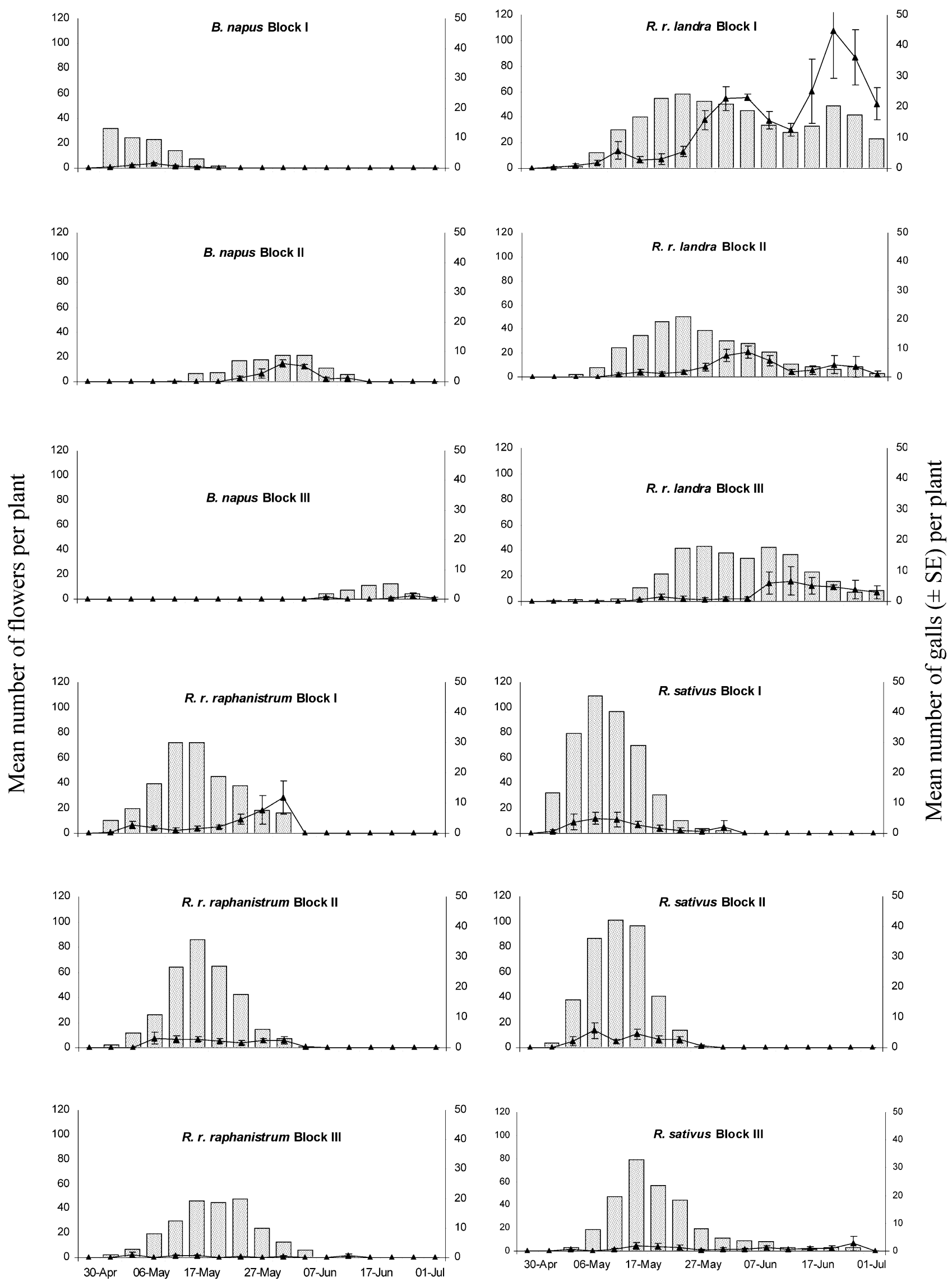

Fig. 1. Mean number of flowers that were not galled (light hatched bars), and number of galls (lines \pm SE) per plant on each plant species and in each block per visit over the time of the experiment. 

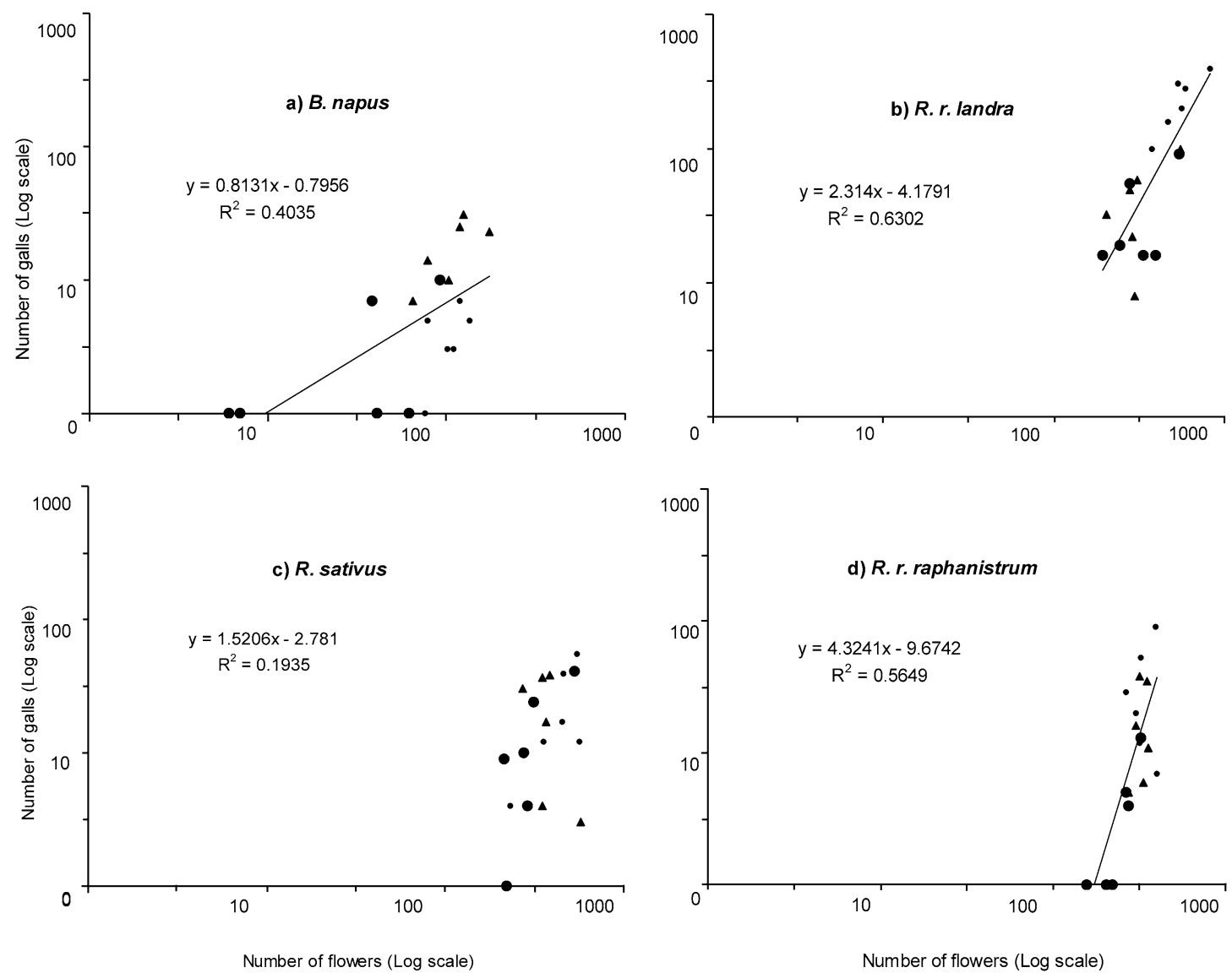

Fig. 2. Regression of the $\log (n+1)$ total number of flowers (x-axis) on $\log (n+1)$ number of galls $(y$-axis) per plant for each test plant species. Small dots represent plants in block 1; triangles plants in block 2; large dots plants in block 3. a) B. napus: $\mathrm{F}_{1,17}=$ $10.82 ; P=0.0046$; b) $R$. $r$. landra $\mathrm{F}_{1,17}=27.27 ; P=0.0001$; c) R. sativus: $\mathrm{F}_{1,17}=3.84 ; P=0.0677$; d) R. r. raphanistrum: $\mathrm{F}_{1,17}=$ $20.78 ; P=0.0003$.

Across the whole experiment, galls appeared in three generational peaks, but as a result of differences in the flowering periods and manipulated flowering phenology, all species per block did not support all three $G$. raphanistri generations. For example, each block of B. napus supported a different midge generation (Fig. 1), while only the resident host $R$. $r$. landra, with the longest flowering period, supported all three midge generations (Fig. 1).

Across the whole experiment, the number of flowers and galls per plant differed significantly between the test plant species. B. napus had a significantly lower number of flowers per plant, while $R$. $r$. landra had a significantly higher number of galls per plant. The mean number of galls per flower was 0.25 for $R$. r. landra, 0.09 for $B$. napus, 0.06 for $R$. r. raphanistrum and 0.05 for $R$. sativus. In each analysis of gall number across the four

TABLE 1. ANOVA table of the $\log (n+1)$ number of galls per plant explained by block, plant species, and $\log (n+1)$ total flower number.

\begin{tabular}{lccccc}
\hline & SS & df $(\mathrm{n}, \mathrm{d})$ & $\mathrm{F}$ & $P$ & $r^{2}$ \\
\hline Blocks & 1.316 & 2,67 & 4.31 & 0.0174 & 0.002 \\
Species & 5.465 & 3,68 & 11.9 & 0.0000 & 0.033 \\
Flowers & 2.261 & 1,66 & 14.8 & 0.0003 & 0.006 \\
Species*Flowers & 2.136 & 3,62 & 4.67 & 0.0053 & 0.005 \\
\hline
\end{tabular}

species, flower number was a significant positive covariate (Fig. 2, Tables 1 and 2).

ANCOVA showed a significant effect of block on the regression of gall number against flower number per plant (Table 1). Significantly fewer galls per flower were found in block 3 (Fig. 3a), which had the latest flowering plants situated farthest from the resident host plant population. There was also a significant effect of plant species on the regression of gall number on flower number (Table 1, Fig. 2). In this ANCOVA, plant species explained more of the variation in galls per plant than either flowers per plant or block (Table 1). There was also a significant interaction between plant species and flower number for gall number per plant in this analysis because the flower number versus gall number per plant relationships varied between plant species, and this relationship for $R$. sativus was not significant (Fig. 2).

TABLE 2. ANOVA table of the mean number per block of Log $(n+1)$ galls per flower explained by $\log (n+1)$ total flower number, plant species and generations.

\begin{tabular}{lccccc}
\hline & SS & df $(\mathrm{n}, \mathrm{d})$ & $\mathrm{F}$ & $P$ & $r^{2}$ \\
\hline Flowers & 4.848 & 1,21 & 35.3 & 0.0000 & 0.307 \\
Species & 0.543 & 3,21 & 1.39 & 0.2735 & 0.004 \\
Generations & 2.067 & 2,23 & 7.52 & 0.0031 & 0.056 \\
\hline
\end{tabular}



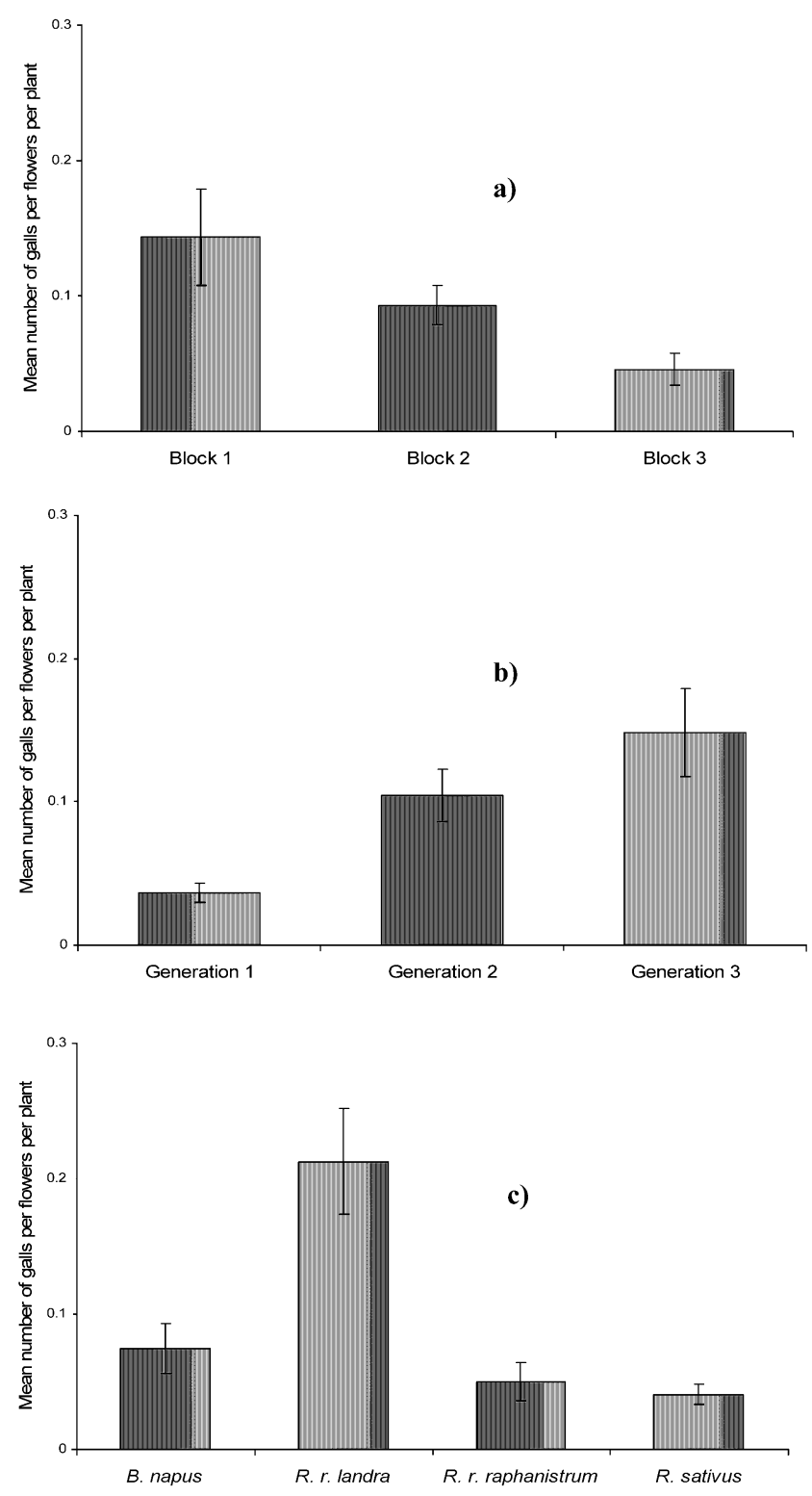

Fig. 3. Mean number ( \pm SE) of galls per total flowers per plant a) per block, b) for generation, c) for plant species.

Finally, an analysis was made of galls produced in relation to the number of flowers available in each of the three gall midge generations (flowers produced in each generational period). In this analysis flower number explained most of the variation in gall number (Table 2). Generation number was also significant with more galls per flower produced in later generations (Fig. 3b), while the effect of host plant species on the number of galls per flower was not significant (Fig. 3c).

\section{DISCUSSION}

\section{The role of host plant phenology}

The confirmed field host range of the gall midge $G$. raphanistri in Europe and the Mediterranean region indicates that it is restricted to $R$. raphanistrum, despite some explainable historical anomalies, with no records from $B$. napus, despite its agricultural importance. This study has shown however, that $B$. napus is within the fundamental host range of $G$. raphanistri for oviposition and development, but that the reason why $G$. raphanistri does not use $B$. napus in the field has a phenological rather than a physiological or behavioural explanation. In spring the flowers of B. napus naturally appear too early for G. raphanistri and the flowering period of B. napus is not long enough to support multiple generations of $G$. raphanistri. In Europe, flowering in winter canola is for agronomic reasons synchronised to occur from early April until late May (Habekotté, 1997). In the region of our study flowering occurs in April (CETIOM, 2006), earlier than the main host, $R$. r. landra. This is clear evidence that host plant phenology can play a strong role in field host plant specificity of gall formers.

By resynchronising the flowering of the potential host plants to suit the emergence and oviposition period of the midge, our study showed that $G$. raphanistri from a natural population can complete development on all the four test plants of Raphanus and Brassica. The test plants differed in the length of the flowering period (Fig. 1), the number of flowers produced and galls that developed throughout the experimental period (Table 2). The number of galls per flower (ANCOVA in Table 2) and the regressions of flower number and gall number (Fig. 2) also differed significantly between test plants. This indicated that $G$. raphanistri exhibits a host species preference of the order; R. r. landra $>B$. napus $>R . r$. raphanistrum $>R$. sativus.

However, the pattern of gall production across the whole experiment, showed 3 clear peaks and the time interval showed these represented 3 generations of $G$. raphanistri (Fig. 1). As such, ovipositing females were not present at all times; therefore the total number of flowers per plant was not the best estimate of available oviposition sites for the midge. Further analysis based on estimates of total flowers available for oviposition showed that any significant effect of host plant species on gall numbers across the whole experiment was due to differences in flower availability between host species (Table 2, Fig. 3c).

The experimental design was arranged in 3 blocks in order of both increasing distance from the natural G. raphanistri population and delayed flowering phenology of the experimental plants. The effects of this are most clearly seen in the B. napus plants, which in each block hosted a different generation of G. raphanistri (Fig. 1). The distance of the blocks from the natural midge population was also evident in that block 3 , which was farthest from the midges and produced flowers last, had fewer galls per flower (Fig. 3c). The effect of midge generation observed across the experiment was also evident as in real terms there were twice as many galls per flower in the third compared to the first generation (Fig. 3b).

Yukawa (2000) emphasizes the importance of synchronization of herbivores with their host plant phenology. The quality and the quantity of food are critical for galling insects such as cecidomyiids that have a limited life span and for which suitable galling sites are flower buds where cell division is actively proceeding. To sup- 
port a population of G. raphanistri in a natural field situation, the host plants would have to produce flowers at a time suitable for oviposition by the midges. In our experiment the test plants were attacked by three generations of the gall midge only because of artificially generated between-block differences in flowering phenology. Under natural conditions in the south of France, B. napus flowers in April (CETIOM, 2006), too early for the first generation of $G$. raphanistri. Furthermore the $R$. r. raphanistrum and $R$. sativus plants only flowered long enough to support two generations of the midge under the Mediterranean climatic conditions of the experiment. This may explain why $R$. $r$. landra is the natural host at the experimental locality and why B. napus is not a host of G. raphanistri in the field in Europe. Raphanus r. raphanistrum is a host of the midge in other situations. It may be that the flowering period of this subspecies may be longer under such situations or there are fewer midge generations (particularly at colder latitudes).

Even so, the long flowering period of $R$. raphanistrum, wide variety of climates and flowering conditions in Europe makes it likely that there will be locations where this specificity breaks down. This probably has not been detected due to the assumption that the galls on this plant are caused by $C$. nasturtii. An alternative explanation is that plant phenology does not completely determine the host specificity in natural conditions although further field tests at a wide range of locations is needed to test this idea.

\section{Field host specificity tests}

The field experiment was designed to create an artificial opportunity for a wider host range for G. raphanistri. Marohasy (1998) describes false positive results as those obtained when feeding or oviposition occurs on a testplant that would not be attacked in the field and when attack occurs on non-hosts positioned close to a target weed. Similarly, Fox (1993), and Finch \& Collier (2000) suggest that apparent host choice decisions by herbivorous insects may be one result of natural selection favouring avoidance of poor quality plants. When the insect encounters a potential host, it is exposed to a complex array of host-associated stimuli (volatile and nonvolatile plant chemicals, as well as visual or tactile stimuli), rather than a single host-associated stimulus. Plants defined as "poor" and "good" hosts can be confused when found together and could result in abnormal feeding and oviposition decisions. Marohasy (1998) concludes that false positives are potentially expensive as they may result in the rejection of a biological control agent that would be safe for release and Barton (2004) mentions that care needs to be taken when interpreting results from "predisposition" host-range testing done under artificial conditions; otherwise promising biocontrol agents could be rejected when in fact they would do minimal non target damage under field conditions.

The target region for this potential biological control project is Australia, where both Raphanus and Brassica species are introduced. Differences in climate and agronomic practice could lead to the weed, $R$. raphanistrum and the crop, B. napus flowering at the same time in the target region. Reeves et al. (1981) give the phenological development of $R$. raphanistrum at Rutherglen in northeastern Victoria. Plants germinating in early autumn have a long flowering period and subsequent germinations, and as a result flowers can be found at most times of the year, although mainly during the winter months. B. napus also flowers in the winter months and flowering time is highly dependent on sowing date, which depends on seasonal rainfall (Farré et al., 2002). As a consequence canola flowers within the overall phenology of $R$. raphanistrum. This implies that flowering time is unlikely to limit the host range of G. raphanistri if introduced into Australia.

This study should be replicated in other areas of Europe under field-like conditions, in order to attempt to understand why the economic literature does not record any other hosts compared to the rich cecidological literature. The difference between the galling of $R$. r. raphanistrum and $R$. r. landra should also be studied more closely because it questions $G$. raphanistri identity, which should be examined further using molecular methods.

Despite the lack of recent literature records of G. raphanistri as a pest of any B. napus-based crop plants, this study found that $G$. raphanistri from a natural population in a natural field setting shows no reduced preference and can complete full development on this crop. High field specificity of this gall midge to Raphanus in Europe is driven by synchrony of oviposition and flower availability and not physiological incompatibility with closely related host genera. Commercially grown Brassica spp. are not suitable hosts for $G$. raphanistri only because of their different flowering phenology compared to Raphanus raphanistrum. This means that the midge is an unsuitable biological control agent of $R$. r. raphanistrum in Australia where the new environment may pose contrasting phenological conditions for both the midge and its potential hosts.

ACKNOWLEDGEMENTS. This study was financed by the Grains Research and Development Corporation of Australia. We thank T. Heard for his comments on the manuscript, C. Jolivet for her help with the experiment at Palavas as part of her Diplôme d'Etudes Approfondies thesis and J.-L. Sagliocco for his help in the field and his relevant records.

\section{REFERENCES}

Abrahamson W.G., Melika G., Scrafford R. \& Csóka G. 1998: Gall-inducing insects provide insights into plant systematic relationships. Am. J. Bot. 85: 1159-1165.

BARnes H.F. 1946: Gall Midges of Economic Importance. Vol. 1. Root and Vegetable Crops. Crosby Lockwood, London, $104 \mathrm{pp}$.

BARTON J. 2004: How good are we at predicting the field hostrange of fungal pathogens used for classical biological control of weeds? Biol. Contr. 31: 99-122.

BuHr H. 1939: Pflanzengallen Mecklenburgs IV. Nachtrag zu den Zoozezidien. Arch. Ver. Freunde Naturg. Mecklenb. (N.S.) 14: 29-70.

CETIOM 2006: Centre Technique Interprofessionnel des Oléagineux Métropolitains, Paris, France, www.cetiom.fr (accessed 31 August 2006). 
Darvas B., Skuhravá M. \& Andersen A. 2000: Agricultural dipteran pests of the Palaearctic Region. In Papp L. \& Darvas B. (eds): Contributions to a Manual of Palaearctic Diptera. Vol. 1. General and Applied Dipterology. Science Herald, Budapest, pp. 565-650.

Farré I., Robertson M.J., Walton G.H. \& Asseng S. 2002: Simulating phenology and yield response of canola to sowing date in Western Australia using the APSIM model. Austr. J. Agric. Res. 53: 1155-1164.

Fedotova Z.A. 1992: New species and genera of gall-midges (Diptera, Cecidomyiidae) living on Brassicaceae in Kazakhstan. Entomol. Obozr. 71: 664-673.

FINCH S. \& CollieR R.H. 2000: Host-plant selection by insects a theory based on "appropriate/inappropriate landings" by pest insects of cruciferous plants. Entomol. Exp. Appl. 96: 91-102.

Fox C.W. 1993: Host confusion and the evolution of insect diet breadths. Oikos 67: 577-581.

Gómez-Campo C. \& Prakash S. 1999: Origin and domestication. In Gómez-Campo C. (ed.): Biology of Brassica Coenospecies. Elsevier, Amsterdam, pp. 33-58.

НАвекотт́ B. 1997: A model of the phenological development of winter oilseed rape (Brassica napus L.). Field Crops Res. 54: $127-136$

HARRIS K.M. 2002: A review of the Cecidomyiidae (gall midges) that are important pests of world food crops. Atti Accad. Naz. Ital. Entomol. Rc. 50: 97-106.

Harris P. \& Shorthouse J.D. 1996: Effectiveness of gall inducers in weed biological control. Can. Entomol. 128: 1021-1055.

Hinz H.L. 1998: Life history and host specifity of Rhopalomyia n. sp. (Diptera: Cecidomyiidae), a potential biological control agent of scentless chamomile. Ann. Entomol. Soc. Am. 27: $1537-1547$

Hound C. 1908-1909: Les Zoocécidies des Plantes d'Europe et du Bassin de la Méditerranée. Vols 1, 2. A. Hermann, Paris.

KIEFFER J.J. 1886: Beschreibung neuer Gallmücken und ihrer Gallen. Z. Naturwiss. Halle 59: 324-333.

Marohasy J. 1998: The design and interpretation of hostspecificity tests for weed biological control with particular reference to insect behaviour. Biocontr. News Inform. 19: $13-21$.

Moore A.D. 1991: Gall formation on the different forms of skeleton weed by Cystiphora schmidti Rubsaamen (Diptera, Cecidomyiidae). J. Austr. Entomol. Soc. 30: 237-238.

PesCHKEN D.P. 1982: Host specificity and biology of Cystiphora sonchi (Diptera: Cecidomyiidae), a candidate for the biological control of Sonchus species. Entomophaga 27: 405-416.

Reeves T.G., Code G.R. \& Piggin C.M. 1981: Seed production and longevity, seasonal emergence, and phenology of wild radish (Raphanus raphanistrum L.). Austr. J. Agric. Anim. Husbandry 21: 524-530.

Scott J.K., Vitou J. \& Jourdan M. 2002: Review of the potential for biological control of wild radish (Raphanus raphanistrum) based on surveys in the Mediterranean region. In Spafford Jacob H., Dodd J. \& Moore J.H. (eds): Proceedings of the $13^{\text {th }}$ Australian Weeds Conference. Plant Protection Society of WA, Perth, pp. 377-380.

Shorthouse J.D. \& Rohfritsch O. 1992: Biology of InsectInduced Galls. Oxford University Press, New York, 295 pp.

Skuhravá M. 1986: Family: Cecidomyiidae. In Soós Á. \& Papp L. (eds): Catalogue of Palaearctic Diptera. Vol. 4. Akadémiai Kiadó (Hungarian Academy of Sciences), Budapest, and Elsevier, Amsterdam, pp. 72-297.
SkUHRAVÁ M. 1991: Gallmücken der Slowakei (Cecidomyiidae, Diptera). VI. Die Zoogeographie der Gallmücken. Zbor. Slov. Nár. Múz. (Prír. Vedy) 37: 85-178.

SKuHRAVÁ M. 1994a: The zoogeography of gall midges (Diptera: Cecidomyiidae) of the Czech Republic. I. Evaluation of faunistic researches in the 1855-1990 period. Acta Soc. Zool. Bohem. 57: 211-293.

SkUHRAVÁ M. 1994b: The zoogeography of gall midges (Diptera: Cecidomyiidae) of the Czech Republic. II. Review of gall midge species including zoogeographical diagnoses. Acta Soc. Zool. Bohem. 58: 79-126.

SkuHravÁ M. \& Franz H. 1989: Familie Cecidomyiidae (Itonididae) In Franz H. (ed.): Die Nordost-Alpen im Spiegel ihrer Landtierwelt. Eine Gebietsmonographie. Wagner, Innsbruck, pp. 67-97.

Skuhravá M. \& Roques A. 2000: Forest dipteran pests of Palaearctic region. In Papp L. \& Darvas B. (eds): Contributions to a Manual of Palaearctic Diptera. Vol. 1. General and Applied Dipterology. Science Herald, Budapest, pp. 651-692.

SKuHRAVÁ M. \& SKRZYPCZYNSKA M. 1983: A review of gallmidges (Cecidomyiidae, Diptera) of Poland. Acta Zool. Cracov. 26: $387-420$.

SkuHravá M. \& SkuhravÝ V. 1997: Gall midges (Diptera: Cecidomyiidae) of Switzerland. Bull. Soc. Entomol. Suisse 70: 133-176.

SkuHRavÁ M. \& SkuhravÝ V. 2005: Die Gallmückenfauna (Diptera, Cecidomyiidae) Südtirols. 5. Gallmücken des Unterlandes. Gredleriana 5: 285-310.

Skuhravá M., SkuhravÝ V. \& Brewer J.W. 1984: Biology of gall midges. In Ananthakrishnan T.N. (ed.): Biology of Gall Insects. Oxford \& IBH Publishing, New Delhi, pp. 169-222.

Skuhravá M., Skuhravý V., Doncev K.D. \& Dimitrova B.D. 1991: Gall midges (Cecidomyiidae, Diptera) of Bulgaria. I. Faunistic researches in the 1978-1987 period. Acta Zool. Bulgar. 42: 3-26.

Skuhravá M., Skuhravý V., Doncev K.D. \& Dimitrova B.D. 1992: Gall midges (Cecidomyiidae, Diptera) of Bulgaria. II. Host plant relations and economic importance. Acta Zool. Bulgar. 43: 23-42.

Skuhravá M., Skuhravý V., Blasco-Zumeta J. \& Pujade J. 1996: Gall midges (Diptera: Cecidomyiidae) of the Iberian Peninsula. Bol. Asoc. Esp. Entomol. 20: 41-61.

Skuhravá M., Skuhravý V., Dauphin P. \& Coutin R. 2005: Gall midges of France. Les Cécidomyies de France (Diptera: Cecidomyiidae). Mém. Soc. Linn. Bordeaux 5: 1-212.

Skuhravá M., SkuhravÝ V. \& Jörgensen J. 2006: Gall midges (Diptera: Cecidomyiidae) of Denmark. Entomol. Medd. 74: $1-94$.

Sobhian R., Littlefield J., Cristofaro M. \& Mann K. 2000: Biology and host specificity of Spurgia capitigena (Bremi) (Diptera: Cecidomyiidae), for the biological control of Euphorbia esula L. in North America. J. Appl. Entomol. 124: 333-338.

Solinas M. 1982: Studi sui ditteri cecidomiidi. IV. Paragephyraulus diplotaxis n. gen., n. sp. Mem. Soc. Entomol. Ital. Genova 60: 315-334.

Stelter H. 1954: Neue Cecidomyidengallen aus Mecklenburg. Arch. Ver. Freunde Naturg. Mecklenb. 1: 231-237.

VAN KLINKEN R.D. \& EDWARDS O.R. 2002: Is host-specificity of weed biological control agents likely to evolve rapidly following establishment? Ecol. Letters 5: 590-596.

Yukawa J. 2000: Synchronization of gallers with host plant phenology. Popul. Ecol. 42: 105-113.

Received February 15, 2007; revised and accepted 25 July 2007 